ИЗВЕСТИЯ АКАДЕМИИ НАУК ЭСТОНСКОН ССР. ТОМ 26 ХИМИЯ * ГЕОЛОГИЯ. 1977, № 1

\title{
К КОРРЕЛЯЦИИ РАЗРЕЗОВ ВИСБЮСКОГО ВОДОПАДА (О. ГОТЛАНД) И ГЛИНТА СЕВЕРНОГО СААРЕМАА (ЭСТОНИЯ) ПО КОРАЛЛАМ
}

Настоящая статья посвящена сопоставлению наиболее крупных естественных разрезов силура - о-ва Готланд (окрестности г. Висбю) и северной части о-ва Сааремаа (клифы Панга, Ниназе, Суурику). На уровне яруса корреляция этих разрезов не вызывает трудностей, так как венлокский возраст обнажающихся в обоих районах отложений был доказан уже во второй половине прошлого столетия. Однако послойное сопоставление разрезов до сих пор не проводилось. Дело в том, что на висбюском глинте широко распространены рифовые образования с весьма специфической для о-ва Готланд фауной колониальных кораллов. Это специфическое со-

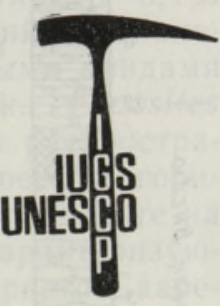

Проект «Экостратиграфия» общество по численности особей столь богато, что почти полностью маскирует тот элемент коралловой фауны, который способен дать существенную биостратиграфическую информацию. С корреляционной точки зрения важно было проследить распространение кораллов в таком разрезе, где биогермы или отсутствуют или имеют второстепенное значение. Этим требованиям наилучшим образом отвечает сводный разрез Висбюского водопада (Wattenfalletprofilen), составленный в 1908 г. Г. Лильеваллом и опубликованный двумя годами позже Х. Хедстрёмом (Hedström, 1910). На послойно собранном Г. Лильеваллом материале кораллов этого разреза, хранящемся в фондах Шведской геологической службы (Sveriges Geologiska Undersökning) в Стокгольме, и основывается настоящая статья. За предоставленную возможность изучить эту коллекцию автор искренне благодарен доктору Р. Скуглунду.

Нижняя часть рассматриваемого разреза (см. таблицу, слой 1) мощностью около 10 с сложена синевато-серым мергелем, содержащим неправильной формы комки и тонкие линзы мелкокристаллического глинистого известняка. К верху карбонатность увеличивается, яснее проявляется слоистость и появляются небольшие строматопорово-коралловые биогермы.

Выше следует примерно 3-метровая пачка (слой 2) желтовато-серых известняков, содержащих детрит криноидей. Местами встречается чистый криноидный известняк. Согласно С. Лауфельду (Laufeld, 1974, с. 8), этот слой представляет собой породу, латерально замещающую биогерм- 


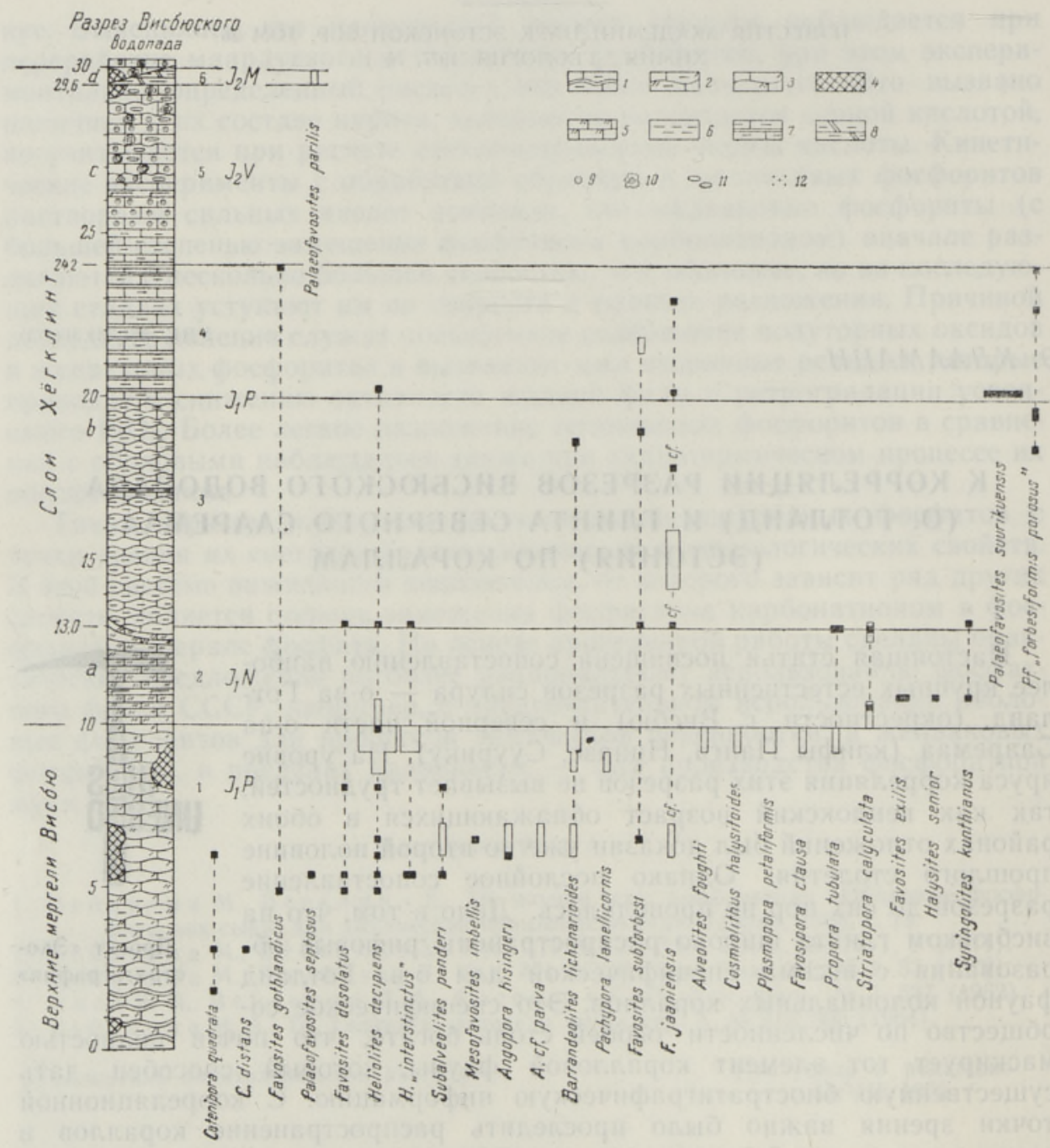

Разрез Висбюского водопада (по Hedström, 1910) и распространение в нем ко раллов. Черные квадраты обозначают находки, привязанные к разрезу с точностью до 20 cм, пустые многоугольники - менее точные сборы. 1 мм ширнны знака соответствует одному экземнлярv. Высотные отметки - абсолютные.

1 - комковатый глинистый известняк с толстыми прослойками мергеля; 2 - среднекомковатый глинистый детритовый известняк; 3 - полукомковатый глинистый детритовый известняк; 4 - биогермный известняк; 5 - крупнодетритовый известняк; 6 чередование известняков и мергелей; 7 - глина; 8 - доломитовые мергели; 9 - оолиты; 10 - онколиты; 11 - галька; 12 - известковые водоросли.

Индексы $\mathrm{J}_{1} \mathrm{P}, \mathrm{J}_{1} \mathrm{~N}, \mathrm{~J}_{2} \mathrm{~V}$ и $\mathrm{J}_{2} \mathrm{M}$ правее от колонки обозначают части разреза, соот ветствующие парамаяской и ниназеской свитам яаниского горизонта и вильсандиским: и маазиским слоям яагарахуского горизонта Эстонии. Номерами от 1 до 6 указаны слои, выделенные в тексте, буквами $a-d$ левее от колонки - подразделения слоев Хёгклинт.

ный известняк. По мере удаления от биогермов этот известняк, в свою очередь, переходит в серый комковатый глинистый известняк и коричневатый глинистый известняк и мергель. В разрезе водопада Висбю в интервале $10-24,2 \mu$ эти три разновидности известняков залегают друг на друге (слои 2-4). 
Интервал 24,2-29,6 м (слой 5) сложен сероватым или коричневатосерым плотным известняком, оолитовым в своей нижней части и имеющим конгломератовую текстуру в верхней.

Разрез венчается темным, местами красноцветным мергелем и битуминозным известняком (слой 6 ) мощностью около 0,5 м, откуда происходят всемирно известные находки скорпиона Palaeophonus nuncius.

Хотя ко времени выхода статьи Х. Хедстрёма еще не существовало современного стратиграфического расчленения силура о-ва Готланд, нет сомнения в том, что в рассматриваемом разрезе мы имеем дело с двумя нижними подразделениями венлока Готланда: с верхними мергелями Висбю в нижней 10-метровой части глинта (слой 1 ) и со слоями Хёгклинт в их полном объеме в интервале $10-30$ м (слон 2-6). Именно в последнем интервале четко прослеживается современное четырехчленное деление слоев Хёгклинт (таблица, $a-d$ левее колонки) (Hede, 1933; Laufeld, 1974).

Кораллы, всего 27 видов, установлены во всем рассматриваемом разрезе в интервале $1,7-30 \mu$. По своему видовому составу комплекс в преобладающей своей части совершенно идентичен с яаниским комплексом Прибалтики и только в самых верхах разреза содержит элементы сообщества низов яагарахуского горизонта. Правда, в промежутке $1,7-5,4$ м еще отмечается присутствие некоторого верхнелландоверийского элемента, однако он представлен отдельными транзитными видами (Catenipora distans Eichw., Palaeofavosites septosus Sok., Favosites gothlandicus Lam., Subalveolites panderi Sok.), максимум распространения которых в Әстонии связан с румбаской свитой адавереского горизонта, но которые спорадически встречаются и в яаниском горизонте на о-ве Сааремаа. В интервале $5-10$ м преобладают виды, характеризующие в Эстонии самые низы $(1-2$ м) разрезов глинта Северного Сааремаа (нижние слои клифов Панга, Суурику, Лийва), сложенные мергелями и глинами: Mesofavosites imbellis Klaam., Favosites subforbesi Sok., Alveolites foughti (M.-Edw. et Haime), Barrandeolites lichenarioides (Sok.) вместе с $F$. desolatus Klaam. и $F$. jaaniensis Sok., известными из стратотипа (клиф Парамая) яаниского горизонта. В нижнюю, глинистую часть готландского глинта попадают также представители таких наиболее характерных для верхних мергелей Висбю видов, как Catenipora quadrata (Fisch.-Benz.), Angopora hisingeri (Jones), Pachypora lamellicornis Lindstr., Favosipora clausa (Lindstr.). По численности экземпляров преобладают, однако, гелиолитоидеи Heliolites decipiens M'Coy, H. «interstinctus» M'Coy, Propora tubulata (Lonsd.) и Plasmopora petaliformis (Lonsd.). Обилие гелиолитоидей также подчеркивает сходство с низами разрезов глинта Северного Сааремаа, единственным пока известным стратиграфическим уровнем в силуре Эстонии, где сконцентрированы гелиолитоидеи. При этом видовой состав комплекса вполне идентичен с готландским составом.

В следующем 3-метровом слое криноидного известняка (слой 2) кораллов мало. Литологически этот известняковый комплекс очень напоминает известняки ниназеской свиты яаниского горизонта Эстонии. Сходство усиливается еще и тем, что здесь, как и на о-ве Сааремаа, начинают появляться ветвистые колонии Striatopora calyculata Lindstr. В Эстонии этот вид впервые был обнаружен в самых базальных слоях ниназеской свиты на клифах Суурику и Панга. В обоих названных местах появление S. calyculata совпадает с появлением брахиоподы Eocoelia angelini (Lindstr.) (Rubel, 1976), присутствие которой в разрезе Готландского глинта прослеживается начиная с этого уровня и кончая верхней границей слоев Хёгклинт (Hedström, 1910). 
Выше криноидного известняка (слой 3) вновь появляется комплекс кораллов, знакомый уже из интервала 5-10 м верхних мергелей Висбю (слой 1). Однако наиболее полно он выявляется лишь на уровне 13,0 13,1 , т. е. в самых низах глинистого комковатого известняка. Возможно, что гипсометрическая привязка материала на зтом уровне разреза не совсем точна и часть экземпляров принадлежит к слою 2.

Выше, в верхней половине слоя 3, многочисленными экземплярами представлен Favosites jaaniensis Sok. (часть форм определена как cf.) руководящий вид табулят стратотипа яаниского горизонта, которому сопутствуют экземпляры Palaeofavosites «forbesiformis porosus», известные в Эстонии из эрратического материала на клифе Парамая и на северном побережье о-ва Муху. Они же характеризуют слой 4, в котором как новый элемент появляется Palaeofavosites suurikuensis Klaam., привязанный в Эстонии к верхним слоям глинта Северного Сааремаа.

Табулят из слоя 5 разреза Висбюского водопада в обработанной коллекции нет, но по личным наблюдениям автора в 1975 г. можно сказать, что эта часть разреза сложена таким же строматопорово-коралловым известняком, как и стратотип яагарахуского горизонта. Здесь обильно представлен Favosites mirandus Sok., практически единственный вид табулят разреза каменоломни Яагараху.

В т. н. Pterygotus-мергеле (слой 6 ) установлен Palaeofavosites parilis Klaam., распространенный на о-ве Сааремаа в биогермах низов маазиских слоев (клиф Куревере, обн. Сепизе).

Представленная картина распространения табулят и гелиолитоидей, а также аналогия последовательности сходных литологических тел глинтов Висбю и Сааремаа позволяют заключить, что интервалы $0-10$ м (слой 1) и 13-20 м (слой 3) в разрезе Висб́юского водопада являют собой аналоги парамаяской свиты $\left(\mathrm{J}_{1} \mathrm{P}\right)$ яаниского горизонта, между которыми залегает сложенный биогермным и криноидным известняком (слой 2) аналог ниназеской свиты $\left(\mathrm{J}_{1} \mathrm{~N}\right)$.

Несмотря на то что интервал $20-24,2$ м Висбюского разреза (слой 4) беден табулятами, наличие типичных форм Favosites jaaniensis Sok. подтверждает его яаниский возраст и позволяет принять его за аналог верхней части парамаяской свиты. С уровня 24,2 м сначала идут оолить, конгломератовые прослои, частые поверхности перерыва и волноприбойные знаки, затем следует биогермный известняк. Эта часть разреза готландского глинта (слой 5) уже соответствует низам яагарахуского горизонта, т. е. наиболее глубокому уровню, обнажающемуся в каменоломнях Яагараху (Einasto, в печати). Кроме наличия здесь Favosites mirandus Sok., об этом же свидетельствуют обнаруженные K. Мори (Mori, 1968) начиная с подразделения $c$ слоев Хёгклинт многочисленные находки строматопороидеи Actinodictyon? tenue Nestor - основного рифостроителя в Яагараху.

Наличие Palaeofavosites parilis Klaam. в последнем слое глинта (слой 6) позволяет сопоставить его с низами маазиских слоев, которые в стратотипическом районе залегают лишь на несколько метров выше разреза карьера Яагараху (Einasto, в печати). Таким образом, птериготусовые мергели о-ва Готланд, вероятнее всего, следует рассматривать как отложения лагунной фации раннемаазиского времени.

Из вышесказанного напрашивается вывод об одновозрастности яаннского горизонта с верхними мергелями Висбю и с бо́льшей частью слоев Хёгклинт, и нижней части яагарахуского (до уровня низов маазиских слоев) - с верхами (слои 5, 6) слоев Хёгклинт. Верхняя граница яа!иского горизонта, проходит, видимо, по подошве подразделения $c$ слоев Хёгклинт. 


\section{Л И ТЕР А Т Р А}

E in a sto R. (trükis). Jaagarahu lademe kolme stratotüübi vanusvahekordadest. Eesti Loodus.

Hed e J. E. 1933. Berggrunden (Silursystemet). In: M u n the H., Hed e J. E., Lund quist G. Beskrivning till kartbladet Kappelshamn. Sver. Geol. Unders., Ser. Aa 171.

Hedström H. 1910. The stratigraphy of the Silurian strata of the Visby district. Geol. Fören. i Stockholm Förhandl., 32, No. 5.

L a.uf eld S. 1974. Silurian Chitinozoa from Gotland. Fossils and Strata, No. 5.

Mori K. 1968. Stromatoporoids from the Silurian of Gotland. Part 1. Acta Univ. Stockh. Stockholm Contributions in Geology, 19.

Rubel M. 1976. Kahe siluri brahhiopoodi esmasleiust Eestis. Geoloogilised märkmed, nr. 3. Tartu.

Ннститут геологии

Академии наук Эстонской ССР

Поступила в редакцию 24/XII 1975

\section{E. KLAAMANN}

\section{VISBY JOA PROFIILI (GOTLAND) JA PÖJA-SAAREMAA PAEKALDA LÄBILOIKE KORRELATSIOONIST KORALLIDE PÖHJAL}

Tabulaatide ja heliolitoidide liigilise koostise ja esinemuse ning kihtide litoloogilise iseloomu järgi Visby joa profiilis (vt. joon.) järeldatakse, et muguljat savikat lubjakivi sisaldavad vahemikud $0-10,13-20$ ja $20-24,2 \mathrm{~m}$ (kihid 1,3 ja 4 ) kujutavad endast jaani lademe paramaja kihistu $\left(\mathrm{J}_{1} \mathrm{P}\right)$ ning vahemik $10-13 \mathrm{~m}$ (peamiselt krinoidlubjakivi, kiht 2) ninase kihistu $\left(\mathrm{J}_{1} \mathrm{~N}\right)$ analoogi. 24,2 meetrist kõrgemal olev läbilõige (kihid 5 ja 6) vastab juba jaagarahu lademele - vilsandi kihtidele $\left(\mathrm{J}_{2} \mathrm{~V}\right)$ ja maasi kihtide $\left(\mathrm{J}_{2} \mathrm{M}\right)$ alumisele osale.

\section{E. KLAAMANN}

\section{ZUR KORRELATION DES WASSERFALLPROFILS VON VISBY (GOTLAND) UND DES GLINTS VOM NÖRDLICHEN SAAREMAA (ESTLAND) NACH KORALLEN}

Aus der Zusammensetzung der Korallenassoziationen, deren Verbreitung und dem lithologischen Charakter der Abblagerungen im Wasserfallprofil von Visby (Abb.) wird gefolgert, daß die Profilabschnitte $0-10,13-20$ und $20-24,2 \mathrm{~m}$ (Schichten 1, 3 und 4) stratigraphische Analogien der Paramaja-Formation der Jaani Stufe $\left(J_{1} P\right)$ Estlands, und das Intervall 10-13 m (hauptsächlich Krinoidkalkstein, Schicht 2) - eine Analoge der Ninase-Formation $\left(\mathrm{J}_{1} \mathrm{~N}\right)$ darstellen. Die Schichten oberhalb des Niveaus von $24,2 \mathrm{~m}$ (Schichten 5 und 6) entsprechen schon der Jaagarahu Stufe - der Vilsandi $\left(\mathrm{J}_{2} \mathrm{~V}\right)$ und dem untersten Teil der Maasi-Formation $\left(\mathrm{J}_{2} \mathrm{M}\right)$. 